\title{
Evaluation the efficacy of volvac $®$ vaccine to Infectious Bronchitis and determine the best rout of administration
}

\author{
M. A. J. Al-Khafaji \\ Coll. of Vet. Med.1/Univ. of AL-Qasem
}

\begin{abstract}
:
Due to Infectious Bronchitis (IB) disease outbreak in Iraq this study was carried out to evaluate the viability of volvac® $\mathrm{IB}+\mathrm{ND}$ MLV as mixed vaccine (Newcastle serotype lasota +infectious bronchitis mass ) which is considered the most common vaccine for IB disease in Iraq and also to determine the most benefit route of administration. This study achieved by using 96 chicks and divided into main 3 groups, each group contain 32 birds, tow groups vaccinated with volvac $\AA$ IB+ND MLV vaccine and the third group is control (-), the first tow groups subdivided in to three sub group each subgroup contain 8 chicks vaccinated with different route .First subgroup(A) vaccinated with dropping route, Second subgroup(B) by spray route and Third subgroup $(\mathrm{C})$ by manual drinking. Antibody of humoral immunity was estimated by using ELISA technique that reveled the vaccine (Newcastle serotype lasota + infectious bronchitis mass ) is benefit for Newcastle disease rather than for Infectious bronchitis, the antibody titer is higher for Newcastle disease than for Infectious bronchitis, and the most useful route is spray.
\end{abstract}

\section{Introduction:}

Avian infectious bronchitis is an acute viral disease of chicken caused by avian infectious bronchitis virus (IBV) and result in highly contagious disease of great economic importance to the poultry industry (20). Infectious bronchitis disease is one of the diseases reported in flocks of layers and broilers in many government of Iraq (1) . Abbas was the first could isolate IB virus in Iraq in1987, then (4) could isolate the IBV from suspected cases of broiler chickens in Mosul. New publication referred to record the disease in Sulaimaneyah (17) where (14) referred to many outbreaks of IB appeared in Baghdad that diagnosed with indirect ELISA technique, also he interpreted that due to vaccination with unsuitable strain of IB , all the IB vaccines, which used are commercially imported and are not matched with serotype that exist in layers and broilers
, finally (2) found that attenuated live vaccines may be regain their virulence and the risk is even greater with viruses that have high frequencies of mutationsIB infection initially recognized as a disease of young chicks which cause respiratory disease or nephritis leads to mortality, reduce weight gain and condemnation at processing exclusion, later it was observed commonly in semi-mature \& laying flock results in reduce egg production \& anomalous egg (6).the inclusion of IBV in office International Des Epizooties (OIE) list B diseases signifies its economic importance. The disease is usually controlled by using live \& inactivated vaccines through spray, ocular or intramuscular injection. Vaccination is only partially successful due to continual emergence antigenic types (11). 


\section{Materials and methods}

\section{1- instruments:-}

Table( 1): Tools and apparatuses used in the study.

\begin{tabular}{|c|c|}
\hline Company (Origin) & Instrument or Equipment \\
\hline Jung - Germany & Digital Balance \\
\hline Synbiotics- USA & ELISA - Reader \\
\hline Synbiotics- USA & ELISA - Washer \\
\hline Gallenkamp, IJK & Incubator \\
\hline Mettler. Switzerland & Sensitive Electrical balance \\
\hline
\end{tabular}

\section{Chemicals :-}

Table(2): Chemicals and solutions used in sterilization of poultry houses.

\begin{tabular}{|l|l|}
\hline Company (Origin) & Chemicals or Solutions \\
\hline Iraq & Ditol \\
\hline BDH - England & Formalin (40\%) \\
\hline Iraq & Potassium Permanganate \\
\hline Fax- Iraq & Sodium Hypochlorite ( Detergent) \\
\hline
\end{tabular}

\section{3 -Serological Tests}

\section{1- Procedure of indirect E LISA Test(} Symbiotic - USA):

The procedure used in this test was performed according to the manufacturer instructions listed in the PToFLOK@ IBV ELISA Kit (Synbiotics-USA), which is a rapid serologic test for the detection of IBV Antibody in chicken serum samples .It was developed primarily to aid in the detection of pre and post-vaccination IBV antibody levels in chickens.

3. 2- Sample Dilution Procedure:

Dilute serum samples using Dilution Buffer in a clean, uncoated 96 well micro titer plate. Setup samples and controls as shown in Figure-1

\begin{tabular}{|c|c|c|c|c|c|c|c|c|c|c|c|c|}
\hline & & & & & (5) & (3) & $\stackrel{7}{9}$ & (3) & คి & 80 & $\stackrel{11}{9}$ & \\
\hline B & (i) & (1) & (i) & (1) & (1) & (i) & (2) & (2) & (i) & (i) & (2) & (ii) \\
\hline c & (2) & (ㄹ) & (ㄹ) & (2)) & (2) & (2) & (2) & (ㄹ) & (2) & (ㅇ) & (1) & (2) \\
\hline D & () & (ㄱ) & (2) & (ㄷ) & () & (2) & (2) & (1) & (2) & () & (). & (2) \\
\hline E & (-) & () & ()) & (-) & (2) & (1) & (;) & (2) & (4) & (3) & (i) & (a) \\
\hline$F$ & (2) & (2) & (2) & (2) & (2) & (2) & (4) & () & () & (2) & (c) & (-) \\
\hline C & (2) & (ㄱ) & (ㄱ) & (2) & () & (우) & (;) & (1) & () & (2) & () & (19) \\
\hline H & (ㅇ) & (). & (). & (1) & (5) & () & $\odot$ & () & (2) & $\odot$ & $(\odot$ & $\odot$ \\
\hline
\end{tabular}

Figure( 1):Micro titer plate test kit. 


\section{3- Preparation of the Serum Dilution Plate}

a) Add $300 \mathrm{pl}$ Dilution Buffer to each well of an uncoated 96 well micro titer plate. This plate is referred to as the serum dilution plate.

b) Add $6 \mu$ unknown serum per well as per Figure 1 (producing a 1:50dilution). Start with well A4 and end with well $\mathrm{H} 9$ (moving left to right ,row by row of wells).

c) Add $6 \mu \mathrm{l}$ of Normal Control Serum (producing a 1.50 dilution) to wells $\mathrm{A} 2 . \mathrm{HIO}$ and $\mathrm{HL}$.

D) Aspirate and remove any liquid in dilution plate wells $\mathrm{Al}, \mathrm{A} 3$ and $\mathrm{H} 11$.

e) Allow all diluted sera to equilibrate in Dilution Buffer for 5 minutes before transferring to an IBV antigen coated ELISA plate.

f) Diluted sera should be tested within 24 hours.

\section{4- Preparation of IBV Positive Control}

An IBV Positive Control Serum has been provided with this kit. Dilute the appropriate volume of IBV Positive Control Serum with Dilution Buffer (1:50) in a clean, glass test tube. For example, dilute 6 $\mathrm{pl}$ of Positive Control serum in $300 \mathrm{pl}$ Dilution Buffer. Mix well. $150 \mathrm{pl}$ of diluted IBV Positive Control is needed per ELISA plate.

\section{5- Preparation of Conjugate Solution}

The horseradish peroxidase conjugated antichicken $\operatorname{IgG}(\mathrm{H}+\mathrm{L})$ is supplied in HRP Stabilizer. Dilute $100 \mathrm{pl}$ stock conjugate in $10 \mathrm{ml}$ Dilution Buffer (1:100 dilution). Mix well. This $10 \mathrm{ml}$ preparation will supply sufficient conjugate for one 96 well ELISA plate.

\section{6- Preparation of IX Wash Solution}

Dilute $20 \mathrm{mI}$ concentrated Wash Solution in $380 \mathrm{ml}$ laboratory grade distilled water (1:20). Mix well. Approximately $400 \mathrm{ml}$ Wash Solution is needed for each9 6 well ELISA plate.

\section{7- Preparation of the Substrate Solution}

The Substrate Solution is ready to use. Each plate will require approximately1 $0 \mathrm{ml}$ substrate solution.For best results ,the substrate solution must be equilibrated to room temperature before use.

\section{8- Preparation of IX Stop Solution}

Dilute $2.5 \mathrm{ml}$ concentrated Stop Solution in $10 \mathrm{ml}$ laboratory grade distilled water (1:5). Mix well. Approximately $12.5 \mathrm{ml}$ Stop Solution is needed for each9 6 well ELISA plate.

\section{9- ELISA Test Procedure}

a) Remove an IBV antigen coated test plate from the protective bag and label according to dilution plate identification.

b) Add $50 \mu \mathrm{l}$ Dilution Buffer to all wells on the test plate.

c) Add 50 pl.1 diluted IBV Positive Control Serum to wells A 1, .A3 and H 1l. Discard pipette tip.

d) Using an 8 or 12 channel pipette transfer5 $0 \mathrm{pl} /$ well of each of the diluted serum samples and Normal Control Serum samples from the dilution plate to the corresponding wells of the IBV coated test plate. Discard pipette tips after each row of sample is transferred .Transfer of samples to the ELISA plate should be done as quickly as possible.

e) Incubate plate for 30 minutes at room temperature.

\section{0- Washing Procedure}

f) Tap out liquid from each well into an appropriate vessel containing bleach or other decontamination agent.

g) Using an 8 or 12 channel pipette (or comparable automatic washing device), fill each well with approximately 300 Wash Solution. Allow to soak in wells for 3 minutes; then discard contents into an appropriate waste container (waste container should contain bleach solution). Tap inverted plate to ensure that all residual liquid is removed. Repeat wash procedure 2 more times.

11-Addition of Anti-Chicken IgG Peroxidase Conjugate, substrate andStop Solution

h) Using an 8 or 12 channel pipette( or transplanting device)dispense 100 diluted 
conjugate( prepared as described above) into each assay well.

\section{Discard pipette tips.}

i) Incubate for 30 minutes at room temperature.

j) Wash as in steps( f )and (g) above.

k) Using an 8 or 12 channel pipette( or transplanting device)dispense1 $00 /$ il Substrate solution into each test well .Discard pipette tips. 1) Incubate1 5minutes at room temperature, $\mathrm{m}$ ) Using an 8 or 12 channel pipette( or transplanting device) add $100 \mu \mathrm{l}$ diluted Stop Solution (prepared as described above)to each test well, n) Allow bubbles to dissipate before reading plate.

\section{2-Manual Processing of Data}

a) Read the plate using an ELISA plate reader set at $405-410 \mathrm{~nm}$. Be sure to blank the reader as directed. b) Calculate the average Positive Control Serum absorbance( Optical Density [O.D.I]) using the absorbance values of wells A1,A3 and H11. Calculate the average Normal Control Serum absorbance using values obtained from wells A2,HIO and HI2. Record both averages.

c) Subtract the average normal control absorbance from the average positive absorbance .The difference is the Corrected Positive Control.

d) Calculate a sample to positive $(\mathrm{Sp})$ ratio by subtracting the average normal control absorbance from each sample absorbance .The difference is divided by the corrected positive control. Use the following equation format:-

\section{$\mathbf{S P}=\underline{\text { Sample Absorbance }- \text { Average Normal Control Absorbance }}$ Corrected Positive Control Absorbance}

e) An IBV ELISA titer can be calculated by the following suggested equation

Titer $=(1.642 \mathrm{X} \mathrm{sp})+3.565$ Titer: Anti log of Titer

\section{3-Reading Results of ELISA}

Assay Control Values:

Valid IBV ELISA results are obtained when the average optical density(O.D.) value of the Normal Control Serum is less than 0,250 and the Corrected Positive Control value range is between 0.250 and 0.900. If either of these values are out of range, the IBV test results should be considered invalid and the samples should be retested. Samples testing with an Sp value of less than or equal to 0.150 will receive a 0 titer value and are considered negative for IBV antibody.

Table 3:- number of drops in each eyes, nose and mouth

\begin{tabular}{|l|l|}
\hline Each eye one drop & eye \\
\hline Each nose one drop & nose \\
\hline Two drops & mouth \\
\hline
\end{tabular}


The other $45 \mathrm{ml}$ is diluted in $2250 \mathrm{ml}$ of distal water randomly, $500 \mathrm{ml}$ used for spray and the $1750 \mathrm{ml}$ for drinking after thirsting .

\section{Results and Discussion}

Infectious bronchitis (IB) is a highly contagious acute viral disease that causes high morbidity in all ages of chickens and high mortality in chicks less than 6 weeks old (6) and it is a major respiratory virus of chickens, as it is probably endemic in all countries that raise chickens (7). A doubt has shown up against some IB vaccines for IB infection, so that this trial was conducted.

\section{Maternal immunity:}

Maternal immunity against IB in this study as revealed by ELIZA was high in titer( table-4) When the development of the

Table 4:- maternal immunity for( IB ) and (ND) by ELISA in one day age.

\begin{tabular}{|c|c|}
\hline ND & IB \\
\hline 9375 & 6870 \\
\hline 9727 & 1028 \\
\hline 2238 & 3090 \\
\hline 10471 & 7079 \\
\hline 4497 & 7227 \\
\hline 3521 & 5467 \\
\hline 6331 & 6126 \\
\hline 7634 & 4711 \\
\hline Mean $=6982,5$ & Mean $=5796,5$ \\
\hline
\end{tabular}

\section{Results of ELISA for chicks against IB and ND at 10 day-old:}

The result of the current study demonstrated high in mean values of reproductive tract of the hens, some of the stimulated lymphocytes localized in the lamina propria of the oviduct and in the stroma of the ovary. Antibody produced locally in these organs usually represented a significant increase of the transferred antibody to the eggs (21). Poultry men usually in Iraq vaccinate their hens before laying using oil adjuvant vaccine mainly volvac ${ }^{\circledR}$ vaccine, and revaccinate hens after few months aerosally. In Europe, this vaccine is one of the commonly used live IB vaccines in commercial poultry, and spray vaccination of broilers at 1 day or 15 days of age generally induces good clinical protection upon challenge with a virulent IBV strain of the same serotype $(10 ; 21$; $8)$.

Table (4): the mean value of antibody titers of ND,IB after 10 days of immunization

\begin{tabular}{|c|c|c|}
\hline Groups & ND & IB \\
\hline A & 1222,3 & 301,3 \\
\hline B & 2773,3 & 618,6 \\
\hline C & 1787 & 146 \\
\hline Control & 174.88 & 133.78 \\
\hline
\end{tabular}


Table (5): The antibody titers of vaccinated groups measured by ELISA test after 10 days of immunization .

\begin{tabular}{|c|c|c|}
\hline Groups & ND & IB \\
\hline A & 1513 & 231 \\
\hline A & 1275 & 324 \\
\hline A & 879 & 349 \\
\hline B & 699 & 333 \\
\hline B & 4819 & 954 \\
\hline B & 2772 & 569 \\
\hline C & 1345 & 111 \\
\hline C & 3564 & 145 \\
\hline C & 452 & 182 \\
\hline
\end{tabular}

The maternal antibody titers could interfere on the response to the first vaccinal stimulus promoting the neutralization of the first vaccination, i.e. high levels of maternal antibody( Mab) titers can interfere with vaccination (5). Vaccinating in the presence of high Mab results in the development of protective local immunity, while the development of high levels of circulating antibodies may be depressed (16). It is known the existence of IBV systemic and local Mab, the first one is responsible for protection against spread of IBV from the respiratory tract to internal organs via blood stream and the local Mab (respiratory tract) is responsible for protection against IBV challenge (14). The Mab is chiefly of the IgG class and become systemic after the intestinal absorption of the yolk. IgG from the mother can be found in the respiratory tract of the progeny, but its role in the protection, as compared to the IgA, is less efficient (18).The results of present study have showed that elevation in $\mathrm{Ab}$ titer in the (B subgroup) could be implicated to the stimulation of local immunity which mediated to the rout of vaccination (coarse spray) that lead to high
$\mathrm{Ab}$ response (mainly $\operatorname{IgA}$ ). These findings are in agreement with (9) who said that the spray vaccination with live attenuated vaccine induce local immunity by massive production of $\operatorname{IgA}$ compaired with a moderate increment in $\mathrm{Ab}$ titer of the (A) subgroup with lower degree of antibody in (C) subgroup our gained data have the same opinion to (13) in Iran who verified that mixed live IB and ND vaccination resulted in higher antibody response by spray route as compared to the dropping route of administration of the vaccine.

\section{Results of ELISA test for chicks against IB at 35 day-old:}

The result has showed that the highest mean value observed in (B)subgroup of ND raised to reach $(6934,6)$, followed by (A) subgroups then(C)subgroup of ND (2719,6 and 8729) respectively compaired with least mean values in IB subgroups (table, 5).The findings in the second subgroup (highest $\mathrm{Ab}$ titer) could be mediated by quick decrement in the Mab at 10 days due to neutralizing Abs with vaccinal strains followed by a booster dose from the same strains which provides a sufficient $\mathrm{Ab}$ titer (secondary immune response). 
Table (6): the mean value of antibody titer for ND, IB by ELISA test after 35 days

\begin{tabular}{|c|c|c|}
\hline Groups & ND & IB \\
\hline A & 2719,6 & 104,66 \\
\hline B & 6934,6 & 228 \\
\hline C & 8729 & 213.66 \\
\hline Control & 1790 & 118 \\
\hline & & \\
\hline
\end{tabular}

Table (7): the antibody values for ND, IB determined by ELISA test after 35 days.

\begin{tabular}{|c|c|c|}
\hline Groups & ND & IB \\
\hline A & 3303 & 92 \\
\hline A & 4027 & 121 \\
\hline A & 2829 & 101 \\
\hline B & 13001 & 337 \\
\hline B & 2566 & 158 \\
\hline B & 4237 & 189 \\
\hline C & 3931 & 262 \\
\hline C & 1291 & 231 \\
\hline C & 2054 & 148 \\
\hline Control & 1790 & 118 \\
\hline
\end{tabular}

The results of the present study agree with (23) who found that the large amount of memory cells were sensitized to produce additional Abs as rapid as possible after second vaccination with the same antigen in first vaccination.In the same manner, the results of the first and the IB subgroup (B) who vaccinated twice with the same vaccine give $\mathrm{Ab}$ titer higher than that, while control group revealed shallow immune response referring to termination of Mab.These results are in accordance with (11), who studied the role of IBV Mab on

\section{References:}

1- Abbass, H.A. (1987). A study of infectious bronchitis in chicken. M.Sc. Thesis - College of Veterinary Medicine - Baghdad University - Iraq.

2- Abdullah, S. M. (2010). Pathogenicity of some infectious bronchitis disease vaccines. M.Sc. Thesis - College of Veterinary Medicine - Baghdad University - Iraq.

3- Adaire, B.M.; Mcnulty, M.S.; Connor, T.J. and Burns, K. (1989). the development of active immunity to vaccine, they found that the Mab declined gradually, remaining on detectable levels up to 17 days. (18) observed that Mab decreased linearly with a mean half-life of five to six days. In contrast, (5) in Brazil, presented no appreciable antibody response to the first vaccinal stimulus $\left(10^{\text {th }}\right.$ day) by the vaccine, in spite of low serum Mab by 10 days. The Mab levels may interfere directly with the response to vaccination, aspects of which have been the subject of certain investigations (8).
Quantitative estimation of Newcastle disease virus antibody level in chickens and turkeys by ELISA. Avian Pathol., 18: 175192.

4- AL-Husairaji, F.F. (2005). Isolation, identification and pathogenesis of infectious bronchitis virus in broilers in Northern area of Iraq. M.Sc. Thesis - College of Veterinary Medicine - Mosul University -Iraq. 
5- Cardoso, W.M.; Aguiar-Filho, J.L.; Romo, J.M.; Oliveira W.F.; Salles R.P.; Teixeira, R.S. and Sobral, M.H. (2006). Interference of infectious bursal disease virus on antibody production against Newcastle disease and infectious bronchitis virus. Braz. J. Poult. Sci., 8: 177-182.

6- Casais, R.; Dove, B.; Cavanagh, D. and Britton, P. (2003). Recombinant avian infectious bronchitis virus expressing a heterologous spike gene demonstrates that the spike protein is a determinant of cell tropism. $\mathrm{J}$. Virol., 77(16): 9084-9.

7- Cavanagh, D. Naqi, S. (2003) Infectious bronchitis, in: Saif Y.M., Barnes H.J., Glisson J.R., Fadly A.M., McDougald L.R., Swayne D.E. (Eds.), Diseases of poultry, Iowa, 11th edition, Ames, Iowa State University Press, , pp. 101-119.

8- Cavanagh , D. (2007). Coronavirus avian infectious bronchitis virus, Institute for Animal Health, Compton Laboratory, Compton, Newbury, Berkshire RG20 7NN, United Kingdom Vet. Res. 38 p 281-297.

9- Darbyshire, J.H., Peters R.W., (1984) Sequential development of humoral immunity and assessment of protection in chickens following vaccination and challenge with avianinfectious bronchitis virus, Res. Vet. Sci. 37:77-86.

10- Davelaar, F.G. Kouwenhoven, B. Burger, A. G. (1983). Occurrence and significance of infectious bronchitis virus variant strain in egg and broiler production in the Netherlands. Vet. Quarterly 6:114120. (Abst. Vet. Bull. 54:7183).

11- Davison, F.; Kaspers, B. and Schat, K.A. (2008). "Avian Immunology". $1^{\text {st }}$ Ed. Printed and
Published by Elsevier Academic Press, UK. : 58-61.

12- Gharaibeh, S.; Mahmoud, K. and AlNatour, M. (2008). Field evaluation of maternal antibody transfer to a group of pathogens in meat-type chickens. Poult. Sci., 87: 1550-1555.

13- Ian, R.T.(2004). "Veterinary Immunology". $7^{\text {th }} \quad$ Ed. Elsevier Publishing Company. USA., : 181197.

14- Khammas, E J. (2008). Avian Influenza (H9N2) outbreak in Iraq. Iraqi J. Vet. Med.Vol.32, No. 1.

15- Kumar, A.N., Jindal, C .L. shukla, Y. Pal, D.R. Ledoux ,and G.E , Rottinghaus , (2004). Pathological changes in broiler chickens fed ochratoxin A and inoculated with Escherichia coli, Avian Pathol. 33:413 - 417 .

16- Ladman, B.S.; Pope, C.R.; Ziegler, A.F.; Swieczkowski, T.; Callahan, C.J.; Davison, S. and Gelb, J.Jr. (2002). Protection of chickens after live and inactivated virus vaccination against challenge with nephropathogenic infectious bronchitis virus PA/ Wolgemuth/ 98. Avian Dis., 46: 938-944.

17- Mahmood, Z. H. Uthman, A. U. (2009) - Detection and identification of avian infectious bronchitis virus in Sulaimania, Microbiology, College of veterinary medicine, Univesity Camp.,Sulaimania, Iraq.

18- Mondal, S.P. and Naqi, S.A. (2001). Maternal antibody to infectious bronchitis virus: its role in protection against infection and development of active immunity to vaccine. Vet. Immunol. Unci. Immtnapath., 79: 31-40.

19- Office International des Epizooties (2008). Avian infectious bronchitis. In: "Manual of 
Standards for Diagnostic Tests and Vaccines" $5^{\text {th }}$ Ed., Paris, : 1-18.

20- Saif, Y.M.; Barnes, H.J.; Glisson, J.R.; Fadly, A.M.; McDougald, L.R. and Swayne, D.E. (2008). "Diseases of Poultry". 12 $2^{\text {th }}$ Ed., Iowa State Univ. Press. Blackwell publishing company, Iowa, USA. : 117-129.

21- Sharma, J. M. (2003). The Avian Immune System. 11th ed. Saif, Y. M.; Barnes, H. J.; Glisson, J. R.; Fadly, A. M.; McDougald, L. R. and Swayne, D. E. ed. Iowa State Press, Ames. Poult. Dis. 5: 5-16.
22- Synbiotic ®. Corporation (2005). Newcastle disease virus antibody test kit. Proflock R. plus. Item No 96-95 33. Frontera San Diego, CA 92127. U.S. Vet LIC No312.

23-Zamani-Moghaddam, A.K.; Mohammad pour, A.A. and Khajali, F. (2007).the effect of live vaccines of Newcastle disease and infectious bronchitis on systemic and local antibody responses in chickens. Iranian J. Vet. Res. Univ. Shiraz, 8: 1-5.

تقييم كفاءة لقاح volvac® IB+ND MLV ضد مرض التهاب القصبات

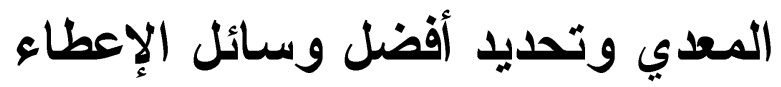

\author{
منى عبد الصاحب جليل الخفاجي \\ كلية الطب البيطري / جامعة القاسم الخضراء \\ الخلاصة
}

لحدوث وباء التهاب القصبات المعدي في العراق ولتوفر الثثك بعدم فعالية بعض اللقاحات المستوردة ضـــــــــا

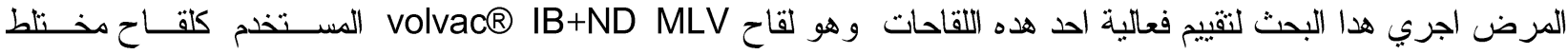

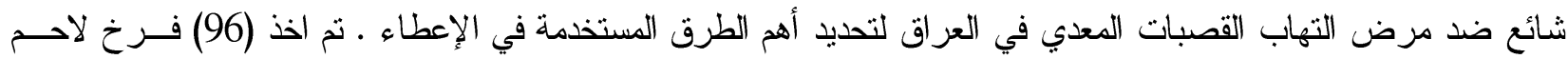

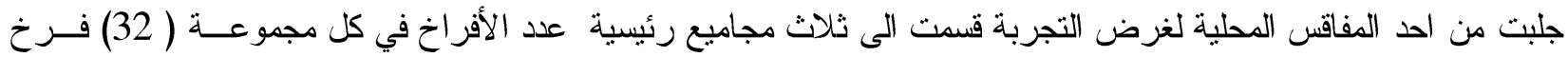

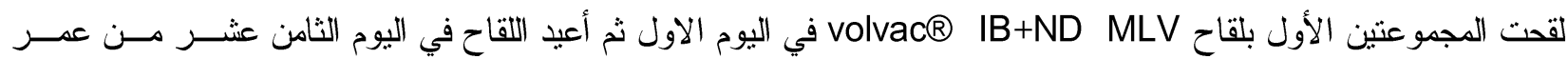
الطير واعتبرت المجموعة الثالثة سيطرة سالبة قست المجموعتين الأوليتين إلى ثلاثت مجـاميع ثانويــة (أ) أعطـي اللقـــاح بطريقة النقطير (ب) بالرش, (ج) بطريقة التجريع اليدوي .أظهرت النتائج فعالية اللقاح ضد مرض النيات النيوكاسل وبدرجة اقـلـل

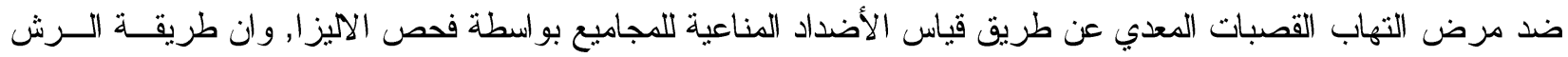
تعتبر أفضل طرق الإعطاء. 